\title{
PENGARUH FAKTOR KEPUASAN KERJA DAN MOTIVASI KERJA TERHADAP KINERJA KARYAWAN PADA DIVISI FINANCE ACCOUNTING DI PT. XYZ CABANG HEAD OFFICE
}

\author{
Jessica Novia \\ Program Studi Magister Manajemen Universitas Tarumanagara \\ jessica051988@gmail.com \\ Anas Lutfi \\ Program Studi Magister Manajemen Universitas Tarumanagara
}

\begin{abstract}
The purpose of this study is to examine employee performance of PT. XYZ branch head office. This problem can be seen from the level of turnover and absenteeism has increase from year to year. This study aims to analyze how the influence of job satisfaction factors and work motivation to employee performance and analyze the dominant factor affecting employee performance. This study examine job satisfaction factors (X1) and Work Motivation (X2) towards employee performance (Y).

The population in this study were all employees of PT. XYZ branch head office. 80 respondents were taken as sample using Google Form and this data in tought with SPSS program version 23 . The analytical method used is multiple regression analysis.

Where all independent variance have positive and significant effect on the dependent variable. Adjusted R Square value is equal to $0,89.89 \%$ showed that employee performance variables described by job satisvaction factors and work motivation. The remaining $11 \%$ of employee performance is explained by other variables.
\end{abstract}

Keywords: Job Satisfaction Factors, Work Motivation and Performance Employee.

\section{PENDAHULUAN}

Dalam menghadapi kehidupan serba modern dengan teknologi canggih dekade ini, peranan Sumber Daya Manusia (SDM) yaitu karyawan / pegawai baik yang bekerja disektor publik maupun swasta) sebagai sumber tenaga kerja dalam suatu unit organisasi yang sangat dibutuhkan untuk menghasilkan produk yang berkualitas, baik berupa materi ataupun produk berupa jasa. Produktivitas pegawai tersebut, saat ini menjadi pusat perhatian dalam upaya meningkatkan kinerja yang mempengaruhi efisiensi dan efektivitas organisasi. Bagi organisasi, suatu pembahasan tentang kepuasan kerja dan motivasi akan menyangkut usahausaha untuk meningkatkan efektivitas organisasi dengan cara membuat efektif perilaku karyawan dalam bekerja. Ketidakpuasan karyawan dan menurunnya motivasi karyawan akan mengakibatkan suatu situasi yang tidak menguntungkan baik secara organisasi maupun individual. Situasi tersebut yang akan mempengaruhi kinerja karyawan. Sebagai seorang individu, pegawai juga mempunyai sesuatu yang utama mengenai perilaku, tabiat dan kebiasaan-kebiasaan yang tumbuh dan berkembang. Kepuasan kerja menjadi faktor determinan utama dari Organizational Citizenship Behavior (OCBC) pekerja. Menurut Wexley dan Yulk (1992) dikutip (Waridin dan Masrukhin, 2006) menyatakan kepuasan kerja merupakan sikap umum seorang individu terhadap pekerjaannya. Menurut Tiffin (1958) dalam Moch. As'ad ( 1995 : 104 ), mengemukakan kepuasan kerja berhubungan erat dengan sikap dari karyawan terhadap pekerjaannya sendiri, situasi kerja, kerja sama antara pimpinan dengan sesama karyawan. Berdasarkan penjelasan diatas dapat disimpulkan bahwa tenaga 
kerja merupakan peran penting dalam mencapai tujuan perusahaan. Adapun permasalahan yang sering terjadi pada PT. XYZ adalah meningkatnya intensitas karyawan yang mengundurkan diri dalam kurun waktu 3 tahun terakhir, yang sebagian besar disebabkan oleh munculnya rasa ketidakpuasan dan menurunnya motivasi karyawan karena kebijakan perusahaan. Kondisi tersebut cenderung disebabkan oleh banyaknya deadline seorang karyawan untuk menyelesaikan tugas seperti pembuatan laporan keuangan tepat waktu atau timbulnya rasa jenuh terhadap pekerjaan.

Berdasarkan latar belakang masalah diatas, maka rumusan masalah dalam penelitian ini adalah:

1. Apakah faktor kepuasan kerja berpengaruh terhadap kinerja karyawan pada PT. XYZ?

2. Apakah motivasi berpengaruh terhadap kinerja karyawan pada PT. XYZ?

3. Apakah kepuasan kerja dan motivasi berpengaruh terhadap kinerja karyawan PT. $\mathrm{XYZ}$ ?

Berdasarkan rumusan masalah dalam penelitian ini, maka tujuan yang ingin dicapai dalam penelitian ini adalah:

1. Untuk mengetahui pengaruh faktor kepuasan kerja terhadap kinerja karyawan pada PT. XYZ.

2. Untuk mengetahui pengaruh motivasi terhadap kinerja karyawan pada PT. XYZ.

3. Untuk mengetahui pengaruh faktor kepuasan kerja dan motivasi terhadap kinerja karyawan pada PT. XYZ.

\section{KAJIAN TEORI \\ Teori Job Satisfaction (Kepuasan Kerja)}

Wexley dan Yulk (1992) dikutip (Waridin dan Masrukhin, 2006) menyatakan kepuasan kerja merupakan sikap umum seorang individu terhadap pekerjaannya. Menurut Tiffin (1958) dalam Moch. As'ad ( 1995 : 104 ), mengemukakan kepuasan kerja berhubungan erat dengan sikap dari karyawan terhadap pekerjaannya sendiri, situasi kerja, kerja sama antara pimpinan dengan sesama karyawan. Masing-masing memiliki tingkat kepuasan berbeda sesuai dengan sistem nilai yang berlaku dalam dirinya. Semakin banyak apek yang sesuai dengan keinginan individu tersebut semakin tinggi kepuasan kerjanya. Dari deskripsi tersebut dapat dikatakan bahwa kepuasan kerja merupakan perasaan seseorang terhadap pekerjaannya dengan mempertimbangkan aspek yang ada didalam pekerjaannya sehingga timbul didalam dirinya suatu perasaan senang atau tidak senang terhadap situasi kerja dan rekan sekerjanya. Apa yang dirasakan individu tersebut dapat positif atau negatif tergantung dari persepsi terhadap pekerjaan yang dilakukan. Pandangan senada dikemukakan Gibson, Ivancevich, dan Donnely (2000:106) yang menyatakan kepuasan kerja sebagai sikap yang dimiliki pekerja tentang pekerjaan mereka. Hal tersebut merupakan hasil dari persepsi mereka tentang pekerjaan. Indikator-indikator kepuasan kerja menurut Celluci, Anthony J dan David L, Deveries (1974) dalam Fuad Mas'ud (2004) dirumuskan kedalam 5 bagian yaitu, kepuasan dengan gaji (satisfaction with pay), Kepuasan dengan promosi (satisfaction with promotion), Kepuasan dengan rekan sekerja (satisfaction with co-wokers), Kepuasan dengan penyelia (satisfaction with supervisor) dan kepuasan dengan pekerjaan itu sendiri (satisfaction with work itself).

\section{Teori Motivation (Motivasi)}

Menurut Pheysey (1993) mengartikan motivasi kerja dalam 2 pengertian yaitu sebagai dorongan untuk bekerja, menjaga agar energy seseorang ditujukan untuk bekerja dan sebagai sebuah alat yang membuat seseorang untuk ingin bekerja. Menurut Gagne et al. dikutip (Hamdani ,2010) mengkategori ulang jenis motivasi menjadi 2 yaitu motivasi terkendali 
(controlled motivation) dan motivasi otonomi (autonomous motivation). Pertama, motivasi terkendali (controlled motivation) disebabkan 2 hal yaitu External regulation dan Introjected regulation. External regulation mengacu pada yang dilakukannya suatu hal untuk memperoleh penghargaan atau menghindari hukuman (punishment). Kebiasaan yang diatur seperti itu tidak dapat terpadu atau terinternalisasi dalam diri seseorang. Dan introjected regulation mengacu pada peraturan atas kebiasaan melalui ketidakpastian terhadap nilai diri seseorang seperti keterlibatan ego dan rasa bersalah sehingga seseorang merasa tertekan secara internal dan timbul internalisasi parsial yang masih terkontrol. Seseorang yang demikian akan melakukan aktivitas tanpa merasa bersalah atau paksaan atau untuk mempertahankan nilai dirinya. Yang kedua motivasi otonomi (autonomous motivation) dibagi menjadi 3 yaitu motivasi karena adanya peraturan yang teridentifikasi (identified regulation), motivasi karena peraturan yang terintegrasi (integrated regulation) dan motivasi intrinsik. Seseorang termotivasi karena peraturan teridentifikasi akan terkait pada kebiasaan dan melakukan suatu hal berdasarkan arti yang dipersepsikan atau tehubung dengan tujuan pribadi.

\section{Teori Employee Performance (Kinerja Karyawan)}

Menurut Byars (1984) dikutip (Kurniawan, 2012) mengartikan kinerja kerja adalah hasil dari usaha seseorang yang dicapai dengan adanya kemampuan dan perbuatan dalam situasi tertentu. Jadi dapat disimpulkan prestasi kerja merupakan hasil keterkaitan antara usaha, kemampuan dan persepsi tugas. Usaha merupakan hasil motivasi yang menunjukan jumlah energi (fisik atau mental) yang digunakan oleh individu dalam menjalankan tugas. Menurut Tsui et all (1997) dikutip Mas'ud, 2004) merumuskan indikator-indikator kinerja karyawan sebagai berikut: kualitas kerja karyawan, standar professional, kuantitas kerja karyawan dan kreativitas.

\section{KERANGKA PEMIKIRAN \& HIPOTESIS PENELITIAN} berikut:

Dalam penelitian ini, kerangka pemikikiran dapat digambarkan dengan bagan sebagai 

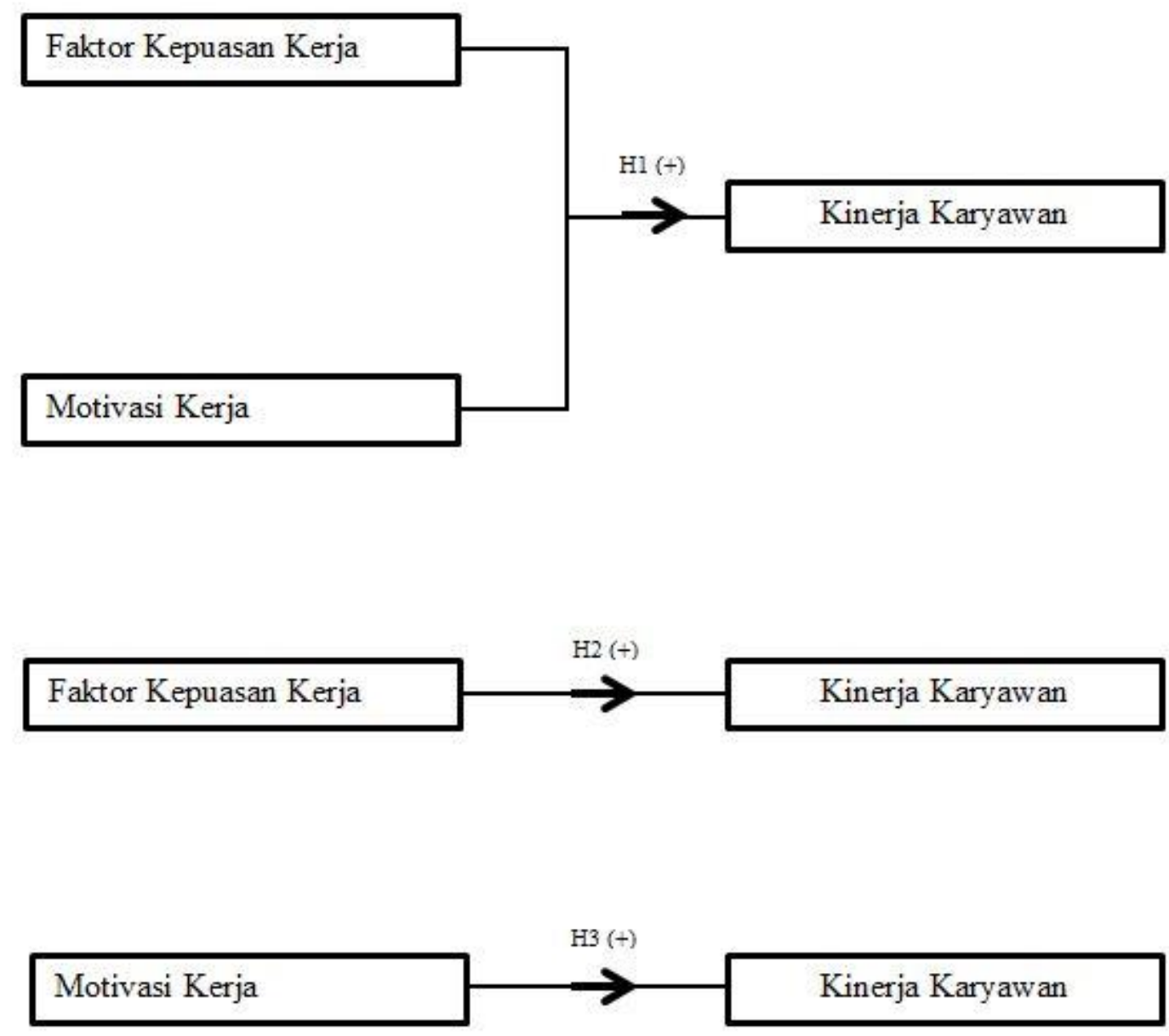

Dari kerangka pemikiran diatas, maka dapat dirumuskan hipotesis sebagai berikut:.

Ha1: Faktor Kepuasan Kerja dan Motivasi Kerja berpengaruh terhadap Kinerja Karyawan.

Ha2: Faktor Kepuasan Kerja berpengaruh terhadap Kinerja Karyawan.

Ha3: Motivasi Kerja berpengaruh terhadap Kinerja Karyawan.

\section{METODE PENELITIAN}

\section{Populasi dan Sampel}

Jenis penelitian ini, dilakukan dengan penelitian kuantitatif kausal. Penelitian kuantitatif adalah penelitian yang datanya berupa angka atau data kualitatif yang diangkakan. Pada penelitian ini juga dijelaskan hubungan sebab akibat dari variabel-variabel yang diteliti sehingga disebut variabel klausal. Penelitian ini dilakukan secara bertahap melalui 4 tahap penting yaitu (1) menyusun dan mengajukan proposal berisi dasar dilakukannya penelitian dan metodenya, (2) mengajukan surat permohonan survey, (4) mengolah data survey dan melaporkan hasil pengujian instrument termasuk uji validitas dan reabilitasnya. Kesemua tahap ini dilakukan dari bulan Januari 2017 hingga Desember 2017. Objek penelitian yang digunakan dalam penelitian ini yaitu karyawan PT. XYZ sebanyak 80 responden..

\section{Definisi Konsep dan Operasional}

Operasional variabel Job Satisfaction (Kepuasan Kerja) X1:

1. Kepuasan dengan gaji (Satisfaction with pay)

2. Kepuasan dengan promosi (Satisfaction with promotion)

3. Kepuasan dengan rekan sekerja (Satisfaction with co-wokers)

4. Kepuasan dengan atasan (Satisfaction with supervisor) 
5. Kepuasan dengan pekerjaan itu sendiri (Satisfaction with work itself)

Operasional variabel Work Motivation (X2)

1. Indentified Regulation

2. Motivasi Intrinsik.

Operasional variabel Kinerja Karyawan (Employee Performance) Y

1. kualitas kerja karyawan

2. Standar professional

3. kuantitas kerja karyawan

4. kreativitas.

\section{HASIL PENELITIAN DAN PEMBAHASAN}

Uji Validitas

Dari hasil output SPSS untuk uji validitas nilai korelasinya dapat dilihat pada kolom Corrected Item-Total Correlation. $\mathrm{r}$ tabel dicari signifikansi 0.05 dengan uji 2 sisi dan $n$ adalah 80, maka nilai $r$ tabel adalah 0.2198. Dari output menunjukkan bahwa $r$ hitung semua item pernyataan lebih dari 0.2198 . Sehingga dapat disimpulkan bahwa semua pernyataan pada variable Job Saticfaction Factor, Work Motivation dan Employee Performance adalah valid.

\section{Uji Reliabilitas}

Reliabilitas berarti terdapat konsistensi dan stabilitas nilai hasil skala pengukuran tertentu. Hal ini mengindikasikan bahwa responden konsistensi dalam memberi tanggapan atas pernyataan yang diajukan. Suatu konstruk atau variabel dikatakan reliabel jika memberikan nilai Cronbach Alpha > 0.7 (Ghozali, 2016), sedangkan menurut Sekaran (1992), reliabilitas kurang dari 0.6 adalah kurang baik. Dan jika nilai Cronbach Alpha >0,9 maka reliabilitas sempurna. Bedasarkan hasil dari analisis reliabilitas dengan teknik Cronbach Alpha, dapat diketahui nilai Cronbach Alpha lebih besar dari 0.7, maka semua instrumen kuesioner dinyatakan reliabel.

\section{Uji Asumsi Klasik}

\section{Uji Normalitas}

Menurut Rusman (2011), Uji normalitas pada model regresi digunakan untuk menguji apakah nilai residual yang dihasilkan dari regresi terdistribusi normal atau tidak. Metode ini diuji normalitas dengan menggunakan uji One Sample Kolmogorov-Smirnov. Residual berdistribusi normal jika nilai signifikansi lebih dari 0,05 . 
One-Sample Kolmogorov-Smirnov Test

\begin{tabular}{|ll|r|}
\hline & & $\begin{array}{r}\text { Unstandardized } \\
\text { Residual }\end{array}$ \\
\hline Normal Parameters & Mean & 80 \\
Most Extreme Differences & Std. Deviation &, 0000000 \\
& Absolute &, 32649847 \\
& Positive &, 085 \\
Test Statistic & Negative &,- 085 \\
Asymp. Sig. (2-tailed) & &, 085 \\
a. Test distributionis Normal. &, $200^{\circ .0}$ \\
\hline
\end{tabular}

Berdasarkan hasil uji normalitas diketahui bahwa nilai signifikansi (Asymp.Sig 2-Tailed) sebesar 0,200, sehingga nilai signifikansi lebih dari 0,05. Nilai residual terdistribusi dengan normal.

Uji Multikolinieritas

Menurut Priyatno (2014), jika nilai Tolerance Value diatas 0,1 dan nilai VIF dibawah 10 maka tidak ada multikolinieritas antara variabel independen.

Tidak terjadi multikolinearitas karena VIF $\leq 10$ dan toleran $>0,10$, dari hasilnya terdapat dalam tabel di bawah ini:

\begin{tabular}{|c|c|c|c|}
\hline & \multicolumn{3}{|c|}{ Hasil Uji Multikolonieritas } \\
\hline & & \multicolumn{2}{|c|}{ Collinearity Statistics } \\
\hline \multicolumn{2}{|c|}{ Model } & Tolerance & VIF \\
\hline \multirow[t]{3}{*}{7} & (Constant) & & \\
\hline & $\mathrm{KP}$ & 278 & 8,859 \\
\hline & $\mathrm{M}$ & 278 & 8.859 \\
\hline
\end{tabular}

\section{Uji Heteroskedastisitas}

Menurut Ghozali (2013) uji heteroskedastisitas bertujuan untuk menguji apakah dalam model regresi terjadi ketidaksamaan variance dari residual satu pengamatan ke pengamatan yang lain.

\section{Hasil Uji Heteroskedastisitas}

\begin{tabular}{|c|c|c|c|c|c|c|}
\hline \multicolumn{7}{|c|}{ Coefficients $^{\mathrm{a}}$} \\
\hline \multirow{2}{*}{\multicolumn{2}{|c|}{ Model }} & \multicolumn{2}{|c|}{ Unstandardized Coefficients } & \multirow{2}{*}{$\begin{array}{c}\begin{array}{l}\text { Standardized } \\
\text { Coefficients }\end{array} \\
\text { Beta }\end{array}$} & \multirow[b]{2}{*}{$t$} & \multirow[b]{2}{*}{ Sig. } \\
\hline & & B & Std. Error & & & \\
\hline & (Constant) & 248 &, 076 & & 3,238 &, 002 \\
\hline & $\mathrm{KP}$ &, 015 &, 068 &, 088 &, 215 & 830 \\
\hline & M &,- 007 &, 072 &,- 039 &,- 096 &, 924 \\
\hline
\end{tabular}

Dalam penelitian ini menggunakan uji heteroskedastisitas pendekatan Glejser, dimana hasil uji nilai sig harus diatas 0.05 untuk dinyatakan tidak terjadi heteroskedastisitas. Sehingga jika dilihat pada tabel 5.14 menunjukkan variabel Kepuasan Kerja nilai Sig. sebesar 0,830 dan variabel Motivasi Kerja nilai Sig sebesar 0,924. Maka dapat disimpulkan bahwa tidak terjadi heteroskedastisitas dikarenakan diatas 0,05. 


\section{PENGUJIAN HIPOTESIS}

\section{Koefisien Determinasi $\left(\mathbf{R}^{2}\right)$}

$\mathrm{R}$ Square $\left(\mathrm{R}^{2}\right)$ yaitu menunjukkan koefisien determinasi. Angka ini akan diubah kebentuk persen, yang artinya persentase sumbangan pengaruh variabel independen terhadap variabel dependen. Nilai $\mathrm{R}^{2}$ sebesar 0,898 yang artinya persentase sumbangan pengaruh dari variabel Kepuasan Kerja (X1) dan Motivasi Kerja (X2) terhadap Kinerja Karyawan (Y) sebesar 89\%, sedangkan sisanya $11 \%$ dipengaruhi oleh variabel yang lainnya yang tidak diteliti dalam penelitian ini.

Model Summary
\begin{tabular}{|l|r|r|r|r|}
\hline Model & $R$ & R Square & $\begin{array}{c}\text { Adjusted R } \\
\text { Square }\end{array}$ & $\begin{array}{c}\text { Std. Error of the } \\
\text { Estimate }\end{array}$ \\
\hline 1 &, $948^{\circ}$ &, 898 &, 896 &, 33071 \\
\hline
\end{tabular}
a. Predictors: (Constant), Kepuasan Kerja, Motivasi Kerja
b. Dependen Variabel: Kinerja Karyawan

\section{Uji Hipotesis}

\section{Uji t}

Berdasarkan hasil penelitian yang telah dilakukan terlihat bahwa nilai signifikansinya variabel Kepuasan Kerja yaitu 0,001 dan Motivasi sebesar 0,000 angka tersebut lebih kecil dari 0,05.Artinya variabel kepuasan kerja dan motivasi berpengaruh secara parsial terhadap kinerja kerja karyawan PT. XYZ.

\section{Hasil Uji t}

\section{Coefficients}

\begin{tabular}{|l|l|r|r|}
\hline \multicolumn{2}{|l|}{ Model } & \multicolumn{1}{c|}{ T } & \multicolumn{1}{c|}{ Sig. } \\
\hline 1 & (Constant) & 1,109 &, 271 \\
\cline { 2 - 4 } & Kepuasan Kerja & 3,625 &, 001 \\
\cline { 2 - 4 } & Motivatian & 3,724 &, 000 \\
\hline
\end{tabular}

\section{Uji F}

Pengujian menggunakan tingkat signifikansi 0,05. Sehingga dari hasil penelitian menunjukkan bahwa nilai signifikansi hasil uji $\mathrm{F}$ adalah lebih kecil dari 0,05 yaitu sebesar 0,000 yang artinya variabel Kepuasan Kerja dan Motivasi Kerja sebagai variabel independen secara bersama-sama (simultan) memiliki pengaruh yang signifikan terhadap Kinerja Karyawan sebagai variabel dependen.

\begin{tabular}{|c|c|c|c|c|c|c|}
\hline \multicolumn{7}{|c|}{$\begin{array}{c}\text { Hasil Uji F } \\
\text { ANOVA }^{a}\end{array}$} \\
\hline & & Sum of Squares & Df & Mean Square & $\bar{F}$ & Sig. \\
\hline \multirow[t]{3}{*}{1} & Regression & 74,453 & 2 & 37,226 & 340,370 &, $000^{\circ}$ \\
\hline & Residual & 8,421 & 77 &, 109 & & \\
\hline & Total & 82,874 & 79 & & & \\
\hline
\end{tabular}




\section{KESIMPULAN}

Berdasarkan hasil penelitian analisa pengaruh faktor kepuasan karyawan dan motivasi kerja terhadap kinerja karyawan, maka dapat disimpulkan antara lain:

a. Faktor Kepuasan Kerja dan Motivasi Kerja berpengaruh secara simultan terhadap Kinerja Karyawan. Hal ini ditunjukkan dari hasil penelitian yang diperoleh nilai signifikansi variabel Faktor Kepuasan Kerja dan Motivasi Kerja secara simultan. Dengan nilai koefisien determinasi (R2) sebesar 0,898 artinya persentase sumbangan pengaruh variabel Faktor Kepuasan Kerja dan Motivasi Kerja sebesar 89\% dipengaruhi oleh variabel lain yang tidak dimasukkan dalam model ini.

b. Faktor Kepuasan Kerja berpengaruh secara parsial terhadap Kinerja Karyawan. Pengaruh dari Faktor Kepuasan Kerja dalam penelitian ini sangat signifikan setelah Motivasi Kerja.

c. Motivasi Kerja berpengaruh secara parsial terhadap Kinerja Karyawan. Pengaruh dari Motivasi Kerja dalam penelitian ini merupakan pengaruh paling besar sumbangsinya dibandingkan Faktor Kepuasan Kerja.

\section{SARAN}

Berdasarkan dari hasil analisa penelitian ini, maka dapat saran yang diberikan antara lain:

a. Faktor Kepuasan Kerja mempengaruhi Kinerja Karyawan pada PT. XYZ cabang Head Office, sehingga pihak perusahaan perlu mengevaluasi penempatan karyawan yang didasarkan pada latar belakang pendidikan, tugas, tanggung jawab, kemampuan karyawan, serta menciptakan lingkungan yang lebih menyenangkan. Sehingga para karyawan merasa betah untuk bekerja dan menimbulkan rasa puas karena dapat mengaplikasikan kemampuannya dalam bekerja.

b. Motivasi Kerja mempengaruhi Kinerja Karyawan pada PT. XYZ cabang Head Office, sehingga perlu dilakukan kegiatan-kegiatan yang dapat membangun rasa semangat (dorongan) yang tinggi untuk menghasilkan kinerja yang lebih baik dan dengan memberikan penghargaan pada karyawan yang berprestasi.

c. Penelitian hendaknya selanjutnya menambahkan variabel lain seperti pengalaman kerja, manajemen waktu dan pendidikan.

\section{PENUTUP}

Penelitian ini dilakukan untuk memperoleh bukti empiris pengaruh Job Satisfaction Factors dan Work Motivation terhadap Employee Performance pada Divisi Finance Accounting di PT. XYZ cabang Head Office

\section{DAFTAR PUSTAKA}

Amir, M.F. (2015). Memahami evaluasi kinerja karyawan. Jakarta: Mitra Wancana Arifin, E. Zaenal. (2008). Dasar - dasar Penulisan Karya Ilmiah. Jakarta: PT Grasindo. Azwar, S. (2005). Metode penelitian. Yogyakarta: Pustaka Pelajar.

Bangun, W. (2012). Manajemen sumber daya manusia. Jakarta: ERLANGGA.

Brahmasari, Ida Ayu dan Suprayetno, (2008). Pengaruh Moivasi Kerja, Kepemimpinan dan

Budaya Organisasi terhadap Kepuasan Kerja serta Dampaknya Pada Kinerja Perusahaan (Studi Kasus PT. Pei Hai Internasional Wiratama Indonesia). Jurnal Manajemen dan Kewirausahan, (Vol.10, No. 2).

Byars, L. L. and L.W.Rue. (1984). Human Resort Management, Mc Graw Hill: New York. 
Duwi Priyatno, (2014). SPSS 22 Pengolah Data Terpraktis. Andi: Yogyakarta.

Gagne,R.M.et al, (2010). Principles of Instructional Design.Fourth Editional. Holt Rinechert and Winston: New York.

Ghozali, Imam. (2016). Aplikasi Analisis Multivariate dengan Programm IBM dan SPSS 23. Edisi 8. Semarang: Badan Penerbit Universitas Diponegoro.

Gibson \& Ivancevich, \& Donnely, (2000). Organiations, Boston: Homewood Kurniawan, Dedi. (2012). Pengaruh Budaya Kerja dan Motivasi Kerja terhadap Kinerja Karyawan International Federations Red Cross. Jurnal Manajemen Pascasarjana Universitas Syiah Kuala (Vol 1-15).

Pheysey, Diana C. (1993). Organizational Cultures, Type And Transformations. Rout-ledge: London and New York.

Tania, Anastasia dan Suryanto, Eddy M. (2013). Pengaruh Motivasi Kerja dan Kepuasan Kerja terhadap Komite Organisasional Karyawan PT. Dai Kinife di Surabaya. Jurnal Agrora, (Vol. 1, No.3).

Tella, Adeyinka. (2007). Work Motivation, Job Satisfaction, and Organizational Commitment of Library Personnel in Academic and Research Libraries in Oyo State, Nigeria Library Philosophy and Practice.

Tiffin, Joseph \& Ernest J. Mc. Cormick (1958). Industrial Psycology, Morusan Co. Ltd. Japan.

Tsui, A.S.,Pearce, J.L. Porter, L.W, dan Tripoli, AM., (1997). Alternative Approaches To The Employee-Organization Relationship: Does Investment to Pay Off.Academy of Management Journal (Vol 40, No:1089-1121).

Uppal, Nishant. Mishra, Sushanta Kumar., \& Vohra, Neharika. (2014). Prior Related Work Experience and Job Performance: Role of personality, International Journal of Selection and Assesment. (Vol 22 (1), No.39-51).

Waridin dan Masrukhin. (2006), Pengaruh Motivasi Kerja, Kepuasan Kerja, Budaya Organisasi dan Kepemimpinan terhadap Kinerja Pegawai. Jurnal Ekonomi \& Bisnis (Vol. 7).

Wexley, Kenneth and Gary Yulk. (1992). Perilaku Organisasi dan Psikologi Personalia. Jakarta: Rineka Cipta. 
